\title{
SELF-ACTUALIZATION NEED IN MAJOR CHARACTER OF WATER FOR ELEPHANTS FILM
}

\author{
Syarif Hidayat \\ Sekolah Tinggi Bahasa Asing - IEC Jakarta \\ kizoku9@gmail.com
}

APA Citation: Hidayat, S (2019). Self-Actualization Need in Major Character of Water for Elephants Film . Journal of English Language and literature, 4(2), 39-46. DOI 10.37110/jell.v4i02.78

Received: 20-07-2019

Accepted: 05-08-2019

Published:01-09-2019

\begin{abstract}
This study analyzes a film entitled Water for Elephants directed by Francis Lawrence, written by Richard Lagravense. The research focuses on how does Jacob try to fulfill and satisfy his self-actualization need viewed from the Hierarchy of human needs of Abraham H. Maslow's Theory? This film is carefully and accurately analyzed using the theory of hierarchy of human needs by Abraham H. Maslow. This research uses the qualitative method. The data are analyzed by watching, underlining, understanding, and identifying it. In this research, it find out that in fulfilling and satisfying his self-actualization need, Jacob has distractions from his lower-order needs. So, he must fulfill and satisfy them first to fulfill and satisfy his self-actualization need. In conclusion, he finally succeeds to fulfill and satisfy his self-actualization need by clearing the distractions from his lowerorder needs which he fulfill and satisfy them first. Furthermore, people who cannot fulfill his basic needs can potentially do an evil thing.
\end{abstract}

Keywords: Humanistic Psychology, Human Needs, Self-Actualization.

\section{INTRODUCTION}

Film as a media which could give a picture of reality, it may give some lessons from the way it illustrates the world around us. Villarejo (2007: 6) writes that "...cinema is dynamic. It animates the world around us; it transports us to worlds we imagine or know only through images." The lessons from the film we may get from the dimensions that appear in it, such as social, philosophical, political or Psychological. It is also written by villarejo (2007:9) that "cinema's dynamism, its capacity to arrange and rearrange time and motion, thus reveals its dimensions that are deeply social, historical, industrial, technological, philosophical, political, aesthetic, psychological, personal, and so forth."

Talking about psychological dimension in film, perhaps it is one of the reasons that there are many studies about psychology in film. It can be argued base on one of theory of psychology which become theory of film, and it is cognitive approach. Indeed, there is a cognitive element in some films. Miller and Stam (2004:105) writes that "Elements of broadly cognitivist thinking can be found in work on film throughout this century (e.g. Munsterberg 1970)." Besides cognitive approach, there is also psychoanalytic approach in studying film, because there are some films which use psychoanalytic ideas. It is also written by Miller and Stam (2004:124) that "film theorists, critics, and commentators have been drawn to psychoanalytic ideas to explain cinema, because cinema seems to display a fundamental kinship with the irrational that psychoanalysis seeks to explain."

In the film of Water for Elephants, there is also psychological aspect. It is neither cognitive nor psychoanalytic. Water for Elephants is a film that tells a story about the life of a young man, Jacob Jankowski. Jacob's father is a Vet. At the beginning of the film, he lives happily with his parents in a house that is not too big and not too small either. His parents seem to love him so much. Jacob is a student of veterinary science in Cornell. He is sure that he will become a Cornell Graduate; and, he knows that he will become a vet. But, while he is 
attending in a final examination for his degree as a veterinarian, suddenly some people come and tell him that a car accident happens and it kills his both parents. That is not the only misfortune that he get at that time, after knowing that his parents are dead, he also knows that his house no longer belongs to him, his parents pawns it to the bank for his college's payment.

His new journey began when he tries to find a job in town, but he never gets there. His destiny brings him into a circus group named Benzini Brothers. An old man named Camel helps him to meet the owner of the circus, August. After telling August that he is a student of veterinary science, August hires him to work to take care of the animals as a vet. There, Jacob works hard and tries to survive. Then, in that circus, he meets a beautiful lady named Marlena, she is the wife of August. He falls in love with her. When Marlena knows that she is in love with Jacob, the conflict between August, Marlena and Jacob begins. August finally knows that Marlena make an affair; she is in love with Jacob. August gets angry, and he tries to kill Jacob. But Marlena warns him, and they both decide to go away together. It is not for too long; the bodyguards of august succeed to find them and take Marlena back to him. Jacob tries to save Marlena. When he comes back to the circus, he finds that Camel was killed. At the same time, Wade and Grady, friends of Camel and Jacob, want to revenge for Camel. They try to destroy the circus. In the one of the show, they make a chaos by letting the wild animal out from the cages. At the time August is killed by Rosie, the elephant that is bought by August, when he tries to kill Marlena. Finally, Jacob succeeds to get Marlena back, and he brought Rosie with him. He decides to take back his final examination and gets a degree as veterinarian. In the end, it is told that Jacob get a job as a veterinarian in Albany zoo and lives happily with Marlena.

From the story above, Jacob is actually a person who is already fulfilled his basic needs; and, he intends to fulfill self actualization need. But, after his parents die, Jacob loses everything including his house. It brings him accidentally to get a job in a circus. There, Jacob fulfills his self-actualization need as a vet. However, he must fulfill his basic needs; since, he does not have anything. Working in the circus, Jacob keeps getting distractions by his basic needs to fulfill his selfactualization need.

It is interested in studying Jacob as a character in the film Water for Elephants because there is the effort of Jacob to fulfill and satisfy his self-actualization need. In analyzing Water for Elephants film, this study focus on: how does Jacob try to fulfill and satisfy his selfactualization need viewed from the Hierarchy of human needs of Abraham H. Maslow's Theory? The result of this study hopefully could be applied as new alternative topic in the subject of literary theory and criticism, so that it could be more various. This study hopefully could give information about how Jacob succeeds to fulfill and satisfy his selfactualization need viewed from the hierarchy of human needs of Abraham H. Maslow's theory

\section{LITERATURE REVIEW}

\section{Character and Characterization}

Character is any individual or fictional people who acts, appears, or is referred to as playing a part in literary work or film. This meaning of character is formed based on some definitions; Pickering and Hoeper (1981:24) writes that "The term character applies to any individual in literary work." Stanford (2006:31-32) writes that "It's not surprising, then, that when we watch television programs, see movies, or read literature, most of us pay close attention to the people - the character-whose lives unfold before us. Letwin, J. Stockdale, and R. Stockdale (2008: 52-53) writes that "Character as meaning the essential nature of dramatic persona-fictional people in a film or play." And, Jerome writes that "He is a character: someone who acts, appears, or is referred to as playing a part in a literary work."

Characters in fiction can be conveniently classified as major and minor, static and dynamic. A major character is an important figure at the center of the story's action or theme. The major character is sometimes called a protagonist whose conflict with antagonist may spark the story's conflict (DiYanni, 2004: 54). Stanford writes, "The protagonist is the major character with whom we generally sympathize, while the antagonist is the character with whom the protagonist is in conflict. The antagonist is generally not sympathetic (Stanford, 2006: 37)." And, supporting the major character are one or more 
secondary or minor characters whose function is partly to illuminate the major characters. Minor characters are often static or unchanging: they remain the same from the beginning of a work to end. Dynamic characters, on the other hand, exhibit some kind of change - of attitude, of purpose, of behavior - as the story progress (DiYanni, 2004: 54).

\section{Maslow's Hierarchy of Human Needs}

This film is carefully and accurately analyzed using the theory of hierarchy of human needs by Abraham H. Maslow. Maslow separated the needs of human into five categories. Physiological needs are the premier biological needs like foods, water, air, house etc. Safety needs is the needs for predictable situation that makes the world sensible. Belongingness and love needs include a psychological need that is so deep to another people. Esteem needs include esteem and respect from themselves and another people. (Friedman and Scuctack, 2006: 353). According to Maslow the right social condition is needed to support people to reach the highest self-actualization; it means that people cannot reach the "being" level (motif B), if they only satisfy their basic needs. We cannot reach the whole of our human's potency and find the truth and beauty if we are lack of foods, safety, love, and esteem. (Friedman and Scuctack, 2006: 353). This research uses the qualitative method. The data are analyzed by watching, underlining, understanding, and identifying the dialogs and scenes of the movie.

\section{METHOD}

In this research, the writer uses qualitative research method. Qualitative research method is a method of research that has purpose to understand the phenomenon which is experienced by the subject of the research such as behavior, perception, motivation, action, etc. (Moleong, 2005: 6). The research is holistically made using a description in the form of words and language at the specific natural context; also using any naturalistic approaches. By using hierarchy of human needs of Abraham Maslow's theory, the writer describes the data qualitatively; to identify how Jacob succeeds to fulfill and satisfy his self-actualization need and how the characteristics of self-actualizing people appear in the character of Jacob in the film of Water for Elephants.

\section{RESULT AND DISCUSSION}

\section{Physiological Needs in Jacob}

Jacob Jankowski is a major character in the film Water for Elephants. It can be argued that Jacob is the central and important figure in this film, because since the story begins until it ends, it is always about him. Jacob Jankowski is a young man about twenty-three years old. His parents come to America from Poland. His father is a veterinarian. Jacob is a student of veterinary science in Cornell University. One day, he attends a final examination for his degree as veterinarian; but, he suddenly gets news that his parents are dead because of car accident. He is forced to resign from the test and it makes he fails in his examination.

After knowing that his house no longer belongs to him, he goes away with intention to find a job in town, but he never gets there. His destiny directs him to jump a circus train and works in the circus named Benzini brothers. There, he meets the owner of the circus, August and some friends, Camel who helps him to meet August, Walter who is his roommate, Grady and Wade. And also, there is a woman named Marlena, the wife of August, whom Jacob falls in love with.

Jacob never goes to the town; in his way to the town, he decides to jump a train that actually a circus train. He is helped by a worker, an old man named Camel to work there. It can be suggested from the picture and dialog below. There is a scene that shows the situation when Jacob Jumps the train, an old man, Camel try to help him.

From the dialog above, it can be known that Camel tries to help Jacob to stay in the train. He also tries to help Jacob to get a job in the circus.

When he comes into the circus, Jacob tries to use his talent and potency as a student of veterinary science, even before he meets August, the owner of the circus of benzini brothers. It can be argued when he looks and notices Silver, a horse that will make a circus show with Marlena, walks tenderly on the foot. In the Movie there is a scene that shows Jacob who tries to check the horse that looks like shaking (Water for Elephants, minutes 0:18:341:18:59)

In the night when the circus make a show in the town, Jacob looks and notices from the 
tent that the horse, silver, is very shaky on his foot, he comes out and offers help to Marlena to check it.

But, there is no time from him to look at into the foot sole of the horse because the horses and Marlena are about to perform. Although, Jacob does not have a chance to check the foot sole of the horse, Jacob knows that the horse gets a disease and he is not going to be able to walk soon. It can be known when Jacob meets august and convinces him about this thing.

Furthermore, Jacob finally gets a chance to check Silver after August hires him as a vet of the circus. In the movie, there is a scene that shows Jacob who checks the foot sole of silver. (Water for Elephants, minutes $0: 29: 14-0: 29: 20)$

The illness of the horse is diagnosed as laminates by Jacob. Indeed, from the picture and dialog above it can be known that Jacob tries to fulfill his self-actualization need. It happens because according to Maslow (1970), "the individual is doing what he, individually, is fitted for"; and, that is what Jacob does. Indeed Jacob tries to fulfill his selfactualization need, but it can be fully satisfied because he still get distraction from his lower need.

The first needs that we have to be fulfilled are physiological needs. Physiological needs are the obvious needs for foods, water, air, sex, sleep, etc. Satisfying those needs is so important for human to survive (Schultz, 1991: 91). A person who is lacking food, self-esteem, and love will demand food first and, until this needs satisfied, will ignore or push all other needs into the background (Goble, 1970: 38)

By getting a job in the circus of benzini brothers, it may solve the problem of Jacob to fulfill his physiological needs especially for food; since, he does not have a place to live and money after his parents die in the car accident. In the movie, there is a scene that shows Jacob who eats greedily, and he is with camel. (Water for Elephants, minutes 0:21:26-0:21:33)

Jacob is helped by Camel in the night when he jumps the train of the circus and Blackie tries to throw him off the train. Camel also helps Jacob by giving him a job to help other workers of the circus so that he can get a food to eat. Jacob is finally given a job in the circus by August after Camel brings Jacob to meet him. Working in the circus guarantees
Jacob to get some food to eat and a place to sleep. So, Jacob can fulfill and satisfy his physiological needs.

\section{Safety Needs in Jacob}

After the Physiological need has been fulfilled, we are driven to satisfy the safety needs. These needs include security, stability, and freedom for fear and anxiety (Schultz, 1991: 91). For infants and children, the safety needs can be seen clearly in their behavior because youngsters react visibly and immediately to any threat to their security. Adults have learned ways to inhibit their reactions to dangerous situations (D. P. Schultz and S.E. Schultz, 2009. 305).

Jacob may fulfill and satisfy his physiological needs, but the distraction also occurs in his safety needs. In the environment that seems not stable in social or economic, the safety needs are not really easy to fulfill and satisfy. Indeed, according to Maslow "If we wish to see these needs directly and clearly we must turn to neurotic or near-neurotic individuals, and to the economic and social underdogs, or else to social chaos, revolution, or breakdown of authority. (Maslow, 1970: 41)". Therefore, Jacob who lives in the circus as a worker is not easy to fulfill and satisfy his safety needs, especially August, the owner of the circus, is that there is a part of him which is undoubtedly very cruel. He will order his bodyguard to throw worker off from the moving train if he knows that this person is not useful anymore from him and the circus.

In the movie, there is a scene that shows Jacob who is going to be thrown off from the train by August's bodyguard (Water for Elephants, minutes 0:36:57-0:37:45). Jacob is going to be thrown off the train by August's bodyguard as August's order when he spontaneously kills silver, the horse that is the star attraction of the circus. Fortunately, it does not happen because it indirectly makes some benefits for august in some points.

Furthermore, there is also a reason why August throws off people from the train, it also happens when the condition of the circus is not really good and he has to banish people to decrease costs. The action of August assert that August also need to fulfill his people's physiologial need and he also needs love from Marlena so that he does not want her injured. 
Jacob : "We had to cancel shows in three towns, the rumor was, four men got tossed to save money. And we might go belly up. Dead circuses were common in '31. Men tired of being mistreated with mutant. Or boss who's at the end come pooling and run with all the money. Leaving a mass of animals and acts like bones to be picked over. Luckily, we found one in Goshen."

(Water for Elephants, minutes 0:38:20-

From Jacob's monolog above, it can describe the cruelty of August, and Jacob feels worried about it. This position goes on to further argue that people who cannot fulfill his basic need can do an evil thing. However, all of these bad events can be a warning for Jacob by looking at what August says in the dialog and Jacob's monolog. So, he has to do the right and the best thing he could and keep away from mistakes that can make August angry. Indeed, it is done by Jacob such as being the bullman and taking care of Rosie, the elephant that is bought by August in Goshen. In the movie, there is a scene that shows Jacob as a bullman who takes care of Rosie, the elephant (Water for Elephants, minutes 0:58:18-0:59:43). By doing these things, it can help Jacob to fulfill his safety needs. Although, it cannot be fully satisfied because he may always feel worried and anxious

\section{Belongingness and Love Needs in Jacob}

Once our physiological and safety needs have been reasonably well satisfied, we attend to the needs for belongingness and love. These needs can be expressed through a close relationship with a friend, lover, or mate, or through social relationships formed within a group (D. P. Schultz and S.E. Schultz, 2009: $305)$.

Furthermore, in the circus, it seems that Jacob's belongingness needs has been fulfilled after a few days he works on the circus. It can be known when Jacob gets a surprising welcome from other workers.

Walter : "This is my new friend and roommate, Jacob. I'd like you all to make him feel at home."

Barbara : "I'd love to make you feel at home."

(Water for Elephants, minutes 0:52:23-

$0: 52: 35)$
In the movie, there is a scene that shows Jacob who gets a surprising welcome from other workers of the circus (Water for Elephants, minutes 0:52:39-0:52:44). Walter, Barbara, and the other workers of the circus get an idea to give Jacob a surprising welcome. It is not really pleasant; but, based on the dialog from Walter and Barbara above; it can be argued that this is made as an indication that they already accept Jacob as a friend, and since then, Jacob will belongs to them. Moreover, Jacob's belongingness needs is also fulfilled by August and Marlena. It can be known when he gets an invitation for dinner from them. In the movie, there is a scene that shows Jacob, August and Marlena who have dinner in August's and Marlena's room (Water for Elephants, minutes 0:48:12).

Jacob may succeed to fulfill and satisfy his belongingness need; but, it does not occur to his love needs. In the film Water for Elephants, Jacob seems to be difficult to fulfill and satisfy his love needs, especially to Marlena, August wife. Jacob may be attracted by Marlena since the first time he meets her when he tries to check silver's foot and it continues when he watch her perform in the circus show. It can be argued from Jacob's monolog below;

Jacob : "She didn't seem real to me at first. The way she looked inside that big tub. Under those lights. I thought I'd go blind from the shine." (Water for Elephants, minutes 0:20:58$0: 21: 08)$

His feeling of liking Marlena becomes a curiosity; it may be a reason why he asks about her to Camel.

Jacob : "Hey Camel - who's
the woman who works with the
horses?"
Camel : "Sshhh that. That ain't no woman
that's the boss's wife marlena. She's
a star attraction, (stops) She don't
talk to nobody and you don't talk to
her. She'll just high hat you
anyway."
(Water for Elephants, minutes 0:23:06$0: 23: 18)$

After several times Jacob meets Marlena, he finally gets a moment to be close to her when August asks both of them to get to know Rosie, the elephant, in the first time she is bought by August. 
From the dialog above, it can be argued that Marlena seems to be worried by the job that is given to her and Jacob. But, Jacob tries to cheer up Marlena by pretending to speak to Rosie and playing her trunk. Finally, Jacob succeeds to lighten Marlena's mood. And then, there is an awkward, lovely moment of intimacy between Jacob and Marlena, especially when Jacob says a title song "confessing that I love you" that seems to be serious. Indeed, this event may cause a deeper feeling of love in Jacob to Marlena.

There is a scene that shows Jacob and Marlena who have a dance in August's and Marlena's room (Water for Elephants, minutes 0:51:04). Dancing with Marlena and looking at her face intimately makes Jacob more in love with Marlena. Further, his love to her makes him nervous to stare face to face with her. It can be known from the dialog above when he responses seriously the statement of Marlena that is actually a title song. And, before the intimate situation comes to be more uncontrolled, Marlena lets Jacob to go.

Jacob does not only need to love, but he also needs to be loved. And he gets it. August, Marlena and Jacob is in the night of party to celebrate that finally Rosie can be trained. After August take some drinks to them, Jacob and Marlena deeply talks to each other.

There is a scene that shows Marlena and Jacob who have a dance in the pub (Water for Elephants, minutes1:13:41). Again, Jacob and Marlena have a dance. From the scene, it can be seen that Marlena looks at Jacob's face with such a deep feeling. Furthermore, when Jacob and Marlena have a dance, there is suddenly a raid. Jacob and Marlena run away separated from August. Then, in the place where they hide, they exchange kisses (Water for Elephants, minutes 1:14:44). There is no doubt that the connection of love between Jacob and Marlena is formed. But, Marlena worries. She goes away and does not let Jacob to follow him. And actually, Jacob worries about August too.

For this reason, Jacob may satisfy his belongingness needs but he cannot satisfy his love needs. It is because he is still distracted by his safety needs. He is worried and not free to love. Jacob's worried even makes him to cannot satisfy his Esteem needs; although, he get an achievement from August himself.

\section{Esteem Needs in Jacob}

Once we feel loved and have a sense of belonging, we may find ourselves driven by two forms of the need for esteem. We require esteem and respect from ourselves, in the form of feelings of self-worth, and from other people, in the form of status, recognition, or social success. Satisfaction of the need for self-esteem allows us to feel confident of our strength, worth, and adequacy, which will help us become more competent and productive in all aspects of our life. When we lack self-esteem, we feel inferior, helpless, and discouraged with little confidence in our ability to cope (D. P. Schultz and S.E. Schultz, 2009: 306).

There is a scene, in the movie, that shows Jacob who get official welcome from August and other workers because of his success to trains Rosie (Water for Elephants, minutes 1:24:28-1:24:45). Jacob gets recognition from August and other workers of the circus, after they succeed to make a spectacular show with a new star of attraction, Rosie, the elephant that is trained successfully by Jacob and August. This recognition is supposed to satisfy Jacob's Esteem needs; but it does not because basically he is still anxious about August. He knows the real August, the one who is so cruel.

Indeed, Jacob's fear and anxiety comes to be real. August finally knows that there is a connection of love between him and Marlena. And then, he intends to kill Jacob.

Marlena tells Jacob that Blackie is given an order to kill Jacob. Hence, Jacob decides to run away from the circus and takes Marlena with him. It can be suggested from the scene that shows Jacob and Marlena who run away from the circus (Water for Elephants, minutes 1:32:46-1:33:10).

Decision to run away from the circus and take Marlena with him describes that Jacob tries to fulfill and satisfy his safety needs and love needs. Again, it is not successful because Blackie, August's bodyguard finds them and takes Marlena back after he beats Jacob. Still, Jacob has a motif to fulfill and satisfy his love needs. He comes back to the circus, and for this time he makes a good plan so that August or even his bodyguard cannot find them.

However, Jacob's plan does not go smoothly. Wade and Grady tries to avenge to August because Walter and Camel are killed by 
Blackie who is given order by August. They let the wild animal out from the cages, and it makes chaos in the circus show. Jacob tries to help Marlena, but August knows it. In the end, August is killed by Rosie when he tries to kill Marlena. It can be known from the scene that shows the chaos in the circus show. (Water for Elephants, minutes 1:42:20:1:45:58). From the character of August, it can be argued that someone who does not fulfill his needs may do an evil thing. August, who loses Marlena, shows that he cannot fulfill his love and esteem needs, that is the reason he try to kill Marlena, but it is stopped by Rosie that kill him first.

With the death of August, Jacob finally gets a freedom from fear and anxiety. It appears that finally, he does fulfill and satisfy his safety needs. Moreover, Jacob also fulfills and satisfies his love needs with Marlena by her side; he loves, and he is loved. And then, after fulfilling and satisfying his love needs; indeed, Jacob must clear the distraction from his esteem need that he fails in his final exam. And, Jacob does it by taking his final test and getting a degree as veterinarian.

It can be argued that by taking the final test and getting a degree, Jacob fulfills and satisfies his esteem needs, because he finally gets esteem and respect from people, it appears when he gets a sweet deal from a circus named Ringling Brothers; and, he gets also esteem respect from himself, and it makes him to feel confident. Yet, he does not feel it before; it can be known when he tells August that he is not a real vet.

\section{Self-Actualization Need in Jacob}

After we satisfy all of basic needs, we are driven by the highest need; self-actualization need. Self-Actualization is the highest development and using the whole of our talent, fulfilling the whole of our quality and capacity. We have to be based on our potency to be. Even though the needs in the lower level have been satisfied- we feel safety physically and emotionally, have a love and belonging feeling, and also we feel that we are respected, but we will be disappointed, uncomfortable and unsatisfied if we failed to fulfill our selfactualization need. If something like that happens, we will be not in peace inside and it cannot be said we healthy psychologically (Schultz, 1991: 93). The individual is doing what $h e$, individually, is fitted for. A musician must make music, an artist must paint, a poet must write, if he is to be ultimately at peace with himself. What a man can be, he must be. He must be true to his own nature. This need we may call self-actualization (Maslow, 1970: 46).

In the end, after Jacob fulfills and satisfies his esteem needs, Jacob finally fulfills and satisfies his self-actualization need. Indeed, he becomes a veterinarian to fulfill and satisfy his self-actualization needs.

By being a veterinarian, it suggests that Jacob use his whole potency and talent that some of them he gets by learning veterinary science in college. Indeed, Jacob feels happy and satisfied because he succeeds to fulfill and satisfy his self-actualization need without any distraction from his basic needs; physiological needs, safety needs, love and belongingness needs, esteem needs. There is no doubt about it, it can be known from the picture above that shows the happiness of Jacob and Marlena, and also from what old Jacob says "and boy that was a life".

Finally, Jacob can be categorized as self-actualizing person because he fulfills and satisfies his self-actualization need; discovering, developing and using his existing potential as a veterinarian who studies veterinary science.

\section{CONCLUSION}

In the film of Water for Elephants, Jacob uses his talent and potency as a student of veterinary science since the first time he comes to the circus. It is suggested when he diagnoses silver's illness, the horse that is the star attraction of the circus. But, unfortunately he has distractions from his basic needs; so, he must fulfill and satisfy them first. Jacob fulfills and satisfies his physiological needs by working in the circus. Jacob gets some food to eat and place to sleep there. Next, Jacob fulfills a part of his safety needs in the circus by being a bullman and taking care of Rosie. Jacob finally fulfills and satisfies his safety needs after August's dead killed by Rosie. After August's dead, Jacob finally can fulfill and satisfy his love and belongingness needs especially with Marlena by her side. It is driven Jacob to fulfill his esteem needs. Then, Jacob fulfills and satisfies his esteem needs by getting his final test. He gets a degree as veterinarian that makes him respecting himself and getting a respect from people by getting a sweet deal with 
the circus named Ringling Brothers. Finally, Jacob fulfills and satisfies his self-actualization need by working in the Albany Zoo as a veterinarian. In brief, it can be concluded that Jacob finally succeeds to fulfill and satisfy his self-actualization need by clearing the distraction from his lower-order needs which he fulfills and satisfies them first. It also can be concluded that people who cannot fulfill his lower needs can potentially do an evil thing. It

\section{REFERENCES}

DiYanni, Robert. (2004). Literature: Approaches to Fiction, Poetry, and Drama. New York: McGraw Hill.

Friedman, Howard S. and Miriam W. (2006). Schustack. Kepribadian: Teori Kalsik dan Riset Modern, Edisi ketiga. Jakarta: Erlangga.

Goble, Frank G. (1970). The Third Force; The Psychology of Abraham Maslow. New York: Washington Square press.

Letwin, David, Joe Stockdale, and Robin Stockdale. (2008). The Architecture of Drama: Plot, Character, Theme, Genre and Style. Maryland: Scarecrow Press, Inc.

Maslow, Abraham. (1970). Motivation and Personality. New York: Harper \&Row.

Miller, Toby and Robert Stam (ed.). (2004). A Companion to Film Theory. Oxford: Bluckwell Publishing.

Moleong, Lexy J. (2005). Metodologi Penelitian Kualitatif. Bandung: PT Remaja Rosdakrya. can be asserted in the case of August, who cannot fulfill his love and esteem need, then tries to kill Marlena. Therefore, someone who do an evil thing can be caused by his or her lack of basic needs, and it is not just because he or she get a mental ill. In conclusion, the idea of humanistic psychology that appears in film and movies, may solve a problem of human kind in real life.

Pickering, James H. and Jeffrey D. Hoeper. Concise Companion to Literature. New York: Macmillan Publishing, Co., Inc., 1981.

Schultz, Duane. (1991). Psikologi Pertumbuhan: Model-model Kepribadian Sehat. Yogyakarta: Kanisius.

Schultz, Duane P. And Sydney E. Schultz. (2009). Theories of Personality: Ninth Edition. Wadsworth: Cangage Learning.

Stanford, Judith A. (2006). Responding to Literature: Stories, Poems, Plays and Essays. New York: McGraw-Hill.

Villarejo, Amy. (2007). Film Studies The Basics. New York: Routledge.

\section{Film (DVD)}

Water for Elephants. Screenplay by Richard Lagravence. Dir. Francis Lawrence. Prod. Gil Netter, Erwin stoff, Andrew R. Tennenbaum. Perf. Reese Witherspoon, Robert Pattinson, Christoph Waltz. Twentieth Century Fox, 2009. DVD. 